\title{
Removal of metallic elements from real wastewater using zebra mussel bio-filtration process
}

\author{
Stefano Magni ${ }^{\mathrm{a}, *}$, Marco Parolini $^{\mathrm{a}}$, Carlo Soave ${ }^{\mathrm{a}}$, Francesca Marazzi ${ }^{\mathrm{b}}$, \\ Valeria Mezzanotte $^{\mathrm{b}}$, Andrea Binelli ${ }^{\mathrm{a}, * *}$ \\ a Department of Biosciences, University of Milan, Via Celoria 26, 20133 Milan, Italy \\ b Department of Environmental and Territory Science, University of Milan-Bicocca, Piazza della Scienza 1, 20126 Milan, Italy
}

\section{A R T I C L E I N F O}

\section{Article history:}

Received 5 November 2014

Accepted 23 January 2015

Available online 28 March 2015

\section{Keywords:}

Zebra mussel

Bio-filtration

Wastewater treatment

Metallic elements

\begin{abstract}
A B S T R A C T
The metallic element pollution is a serious environmental problem but still unsolved since these contaminants are released mainly by human activity, reaching all the environmental compartments. Traditional wastewater treatment plants are very efficient in removing metallic elements only when their concentration is in the order of $\mathrm{mg} / \mathrm{L}$, but are not able to remove them until $\mu \mathrm{g} / \mathrm{L}$, as it would be needed to cope with the water quality standards in low flow receptors. Therefore, the aim of our study was to evaluate the potential removal of some recalcitrant metallic elements to the classical treatments, by the natural process of bio-filtration performed by the invasive zebra mussel (Dreissena polymorpha). For this purpose we built a pilot-plant at the Milano-Nosedo wastewater treatment plant, where we placed about $40,000 \mathrm{D}$. polymorpha specimens appointed to the wastewater bio-filtration. The metallic element removal due to zebra mussel activity was evaluated in the treated wastewater with a plasma optical emission spectrometry (ICP-OES). Data obtained in these experiments showed an encouraging metallic element removal due to $D$. polymorpha activity; in particular, the total abatement (100\%) of $\mathrm{Cr}$ after one day of bio-filtration exposure is remarkable. Therefore, this study encourages further research related with the use of bivalves as a new tool for the wastewater depuration process; in this regard, the contaminated mollusks used in the bio-filtration could be incinerated or stored in special landfills, as is also the case of traditional sewage sludge.
\end{abstract}

(๖2015 Elsevier Ltd. All rights reserved.

\section{Introduction}

Metallic element (ME) pollution is a major global concern since these inorganic contaminants are continuously released into the environment by human activities [1,2]. The ability of these compounds to be accumulated in the organisms and to trig the onset of diseases and disorders makes MEs very dangerous for many organisms, including humans, at very low concentrations [3]. In particular, the water pollution due to MEs is a serious and partially unsolved issue because the removal needed to reach acceptable concentrations in the receiving waters (in the order of $\mu \mathrm{g} / \mathrm{L}$ ) is well over the efficiency of wastewater treatment plants (WWTPs), normally reported as between 40 and 90\% [4]. Because

\footnotetext{
Abbreviations: MEs, metallic elements; WWTPs, wastewater treatment plants.

* Corresponding author. Tel.: +39 0250314729; fax: +39 0250314713.

** Co-corresponding author. Tel.: +39 0250314714; fax: +39 0250314713.

E-mail addresses: stefano.magni@unimi.it (S. Magni), andrea.binelli@unimi.it (A. Binelli)
}

of this reason, alternative methods for the ME abatement have been identified in order to be complementarily applied to traditional wastewater treatment processes. However, most of these techniques, such as precipitation/neutralization, ion exchange, membrane separation, reverse osmosis, electrodialysis and activated carbon adsorption [5-7] have high costs for the regeneration of resins or activated carbons and/or for the disposal of chemical sludge or concentrates [8]. Therefore, the attention of the scientific community need to be focused on the development of natural methods which were more eco-sustainable and, possibly, less expensive. In this regard, biosorption is a possible natural method for ME elimination; this term defines the passive pollutant uptake from an aqueous solution by a dead or non-growing microbial biomass $[9,10]$. Although this treatment has the advantage to not undergo inhibition due to the pollutants' toxicity, the early biomass saturation by adsorbing contaminants represents an important limitation for further exploitation of this process [7]. In addition to the biosorption, the bioaccumulation process of many organic and inorganic contaminants by different aquatic microorganisms such as fungi, algae, bacteria and yeast 
[11,12] may be considered. In particular, bioaccumulation due to microorganisms living on aquatic macrophyte tissues is correlated with ME removal in constructed wetlands. This methodology is certainly the most used natural system of wastewater treatment, which couples accumulation in microbial biomass and in macrophytes such as Phragmites australis,Eichhornia crassipes and Lemna spp. [13-16]. This alternative method, in addition to the removal of MEs, also reduces organic matter and nutrients from wastewater [16]. Despite the existence of these eco-friendly methodologies, in recent years, further studies have been conducted in order to identify new methods for natural purification of waters from some recalcitrant pollutants. In this regard, it is of great interest the research carried out by Ledda et al. [17] aimed at assessing how small breeding of Mediterranean sponges Ircinia variabilis and Agelas oroides could remove some contaminants from marine waters. In the same way, the use of other filtering organisms can be interesting for the improvement of waters quality. In this context, the freshwater bivalve Dreissena polymorpha has some characteristics that would make it suitable for the above mentioned purpose: an enormous filtering capacity, ranging from 5 to $400 \mathrm{~mL} /$ bivalve/h [18,19], a high population density, with more than 700,000 individuals $/ \mathrm{m}^{2}$ [20], and the ability to produce feces and pseudofaeces where many contaminants are adsorbed. In fact, these two $D$. polymorpha waste products, being settleable [21], could easily remove from the water column the bounded pollutants (as MEs). Moreover, taking into account the indirect ability of bivalves to bioaccumulate many environmental contaminants, including MEs [22], we can point out the potential of $D$. polymorpha to this purpose [23-26]. In this regard, a study conducted in 1983 by Piesik [27] highlighted how D. polymorpha is able to remove nutrients from eutrophic waters and a subsequent research confirmed the potential of $D$. polymorpha in the reduction of algal density [28]. In the last two decades, several other studies have demonstrated the filtering capacity of this bivalve, whose breeding could be developed for an alternative treatment of polluted freshwaters [25,29-31]. In this regard, a recent study conducted by Binelli et al. [21] showed the ability of this mollusk to remove different types of emerging contaminants, such as pharmaceuticals and drugs of abuse, from wastewaters. Nevertheless, it is important to take into account that D. polymorpha is considered an invasive alien species all over Europe and the United States, even if this mollusk was present in Europe before the last glaciation [32] and was then bounded in some basins of Eastern Europe in the post-glacial period until the 18th century [33]. The human activity has then favored the distribution of $D$. polymorpha all over its original European areal; in Italy, for example, this bivalve has first been found in 1973 [34] and its presence in the Italian inland waters has been confirmed by subsequent studies

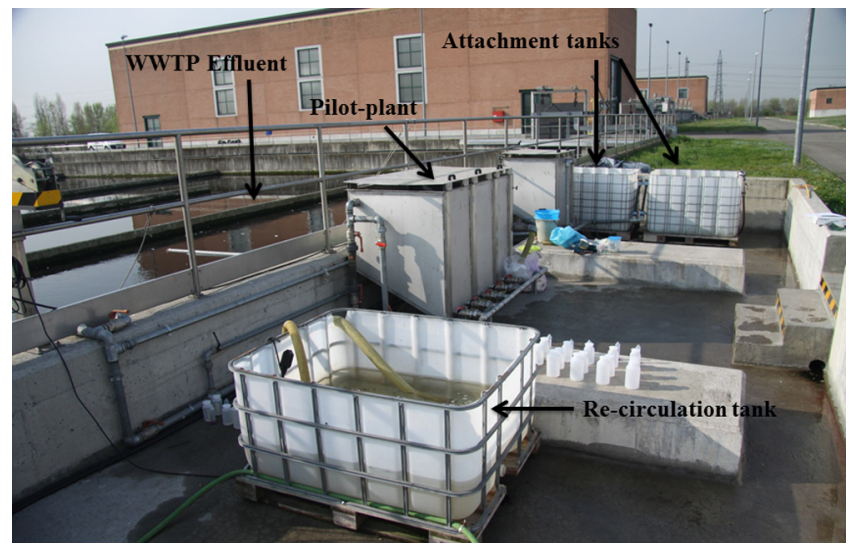

Fig. 1. Structure of the pilot-plant located at the Milano-Nosedo WWTP.
[35-37]. Therefore, the idea of using this invasive species for anthropic purposes (bio-filtration, human food, animal feed, fertilizer and biogas) [29] would be of huge interest, especially in the economic sphere. On the basis of these above mentioned studies on $D$. polymorpha, we assessed the efficiency of this bivalve as a new biological method as the last step of wastewater treatment in a conventional WWTP. For this purpose, we built at the Milano-Nosedo WWTP (Northern Italy) a pilot-plant in which $40,000 \mathrm{D}$. polymorpha specimens were added in order to filtrate some types of wastewaters and we subsequently evaluated the abatement of some MEs, such as Aluminum ( $\mathrm{Al})$, Chromium $(\mathrm{Cr})$, Copper $(\mathrm{Cu})$, Iron (Fe), Manganese (Mn), Nickel (Ni) and Lead ( $\mathrm{Pb})$. This study is particularly innovative because, according to our knowledge, for the first time, D. polymorpha has been used in a real civil WWTP for the removal of some micropollutants. In fact, the few studies conducted using $D$. polymorpha as bio-filtering agent mostly evaluated algal or organic matter removal, but not the abatement of emerging contaminants (as previously reported in Binelli et al.) [21] or potentially toxic metals.

\section{Materials and methods}

Pilot-plant construction and placement at the Milano-Nosedo WWTP

A scuba diver collected the bivalves from the Lake Maggiore and Lake Lugano, both located close to the Italy-Switzerland border. Since it is well-known that $D$. polymorpha is a biofouling organism [38], we placed approximately 40,000 specimens in an attachment tank in order to let them naturally re-adhered to twenty Plexiglas ${ }^{\circledR}$ panels (size: $70 \times 40 \mathrm{~cm}$; Fig. 1 ) via their byssus over a period of 2 weeks. During this acclimatization period, the bivalves were kept in tap water and fed with the blue-green alga alga Spirulina spp. The Plexiglas ${ }^{\circledR}$ panels were then placed into the pilot-plant (Fig. 1), a stainless steel tank with a volume of about $1000 \mathrm{~L}(\mathrm{~L}=154.0 \mathrm{~cm}$, $h=102.0 \mathrm{~cm}, w=80.5 \mathrm{~cm}$ ), where were disposed following a zigzag pathway (yellow line, Fig. 2), in order to increase both the surface and the contact time between the wastewater and each bivalve. In addition to the steel tank, we installed a recirculation tank (Fig. 1) with a volume of $200 \mathrm{~L}$ with a submerged pump to allow a constant wastewater flow $(3500 \mathrm{~L} / \mathrm{h})$ into the pilot-plant. The recirculation tank further increases the contact time between the wastewater and the filter-feeding bivalves placed into the pilotplant, as well as limits the efficiency of settling which would remove part of the contaminants adsorbed on suspended solids. The pilot-plant can directly collect the effluent from the canal placed between the sedimentation tanks and the sand filters of the Nosedo WWTP using a submersible pump $(0-5000 \mathrm{~L} / \mathrm{h})$. The installation site of the pilot-plant allows to test a clarified effluent and to avoid the risk that suspended solids cannot only compromise the filtration capability of bivalves but also cause the animal death due to gill occlusion. Moreover, the pilot-plant position into the Nosedo WWTP guaranteed the lack of any possible accidental release of $D$. polymorpha specimens into the surrounding environment because the sand filters and the following process of disinfection with peracetic acid stop and kill any possible leaked organism.

\section{Evaluation of D. polymorpha filtration ability}

The preliminary tests designed to evaluate the filtering and purifying performance of $D$. polymorpha have been described in detail by Binelli et al. [21]. In that study, the following issues have been discussed: (1) the adaptation of $D$. polymorpha to wastewater; (2) the estimation of $D$. polymorpha filtering efficiency; and (3) the analysis of $D$. polymorpha capacity in the removal of new classes of 


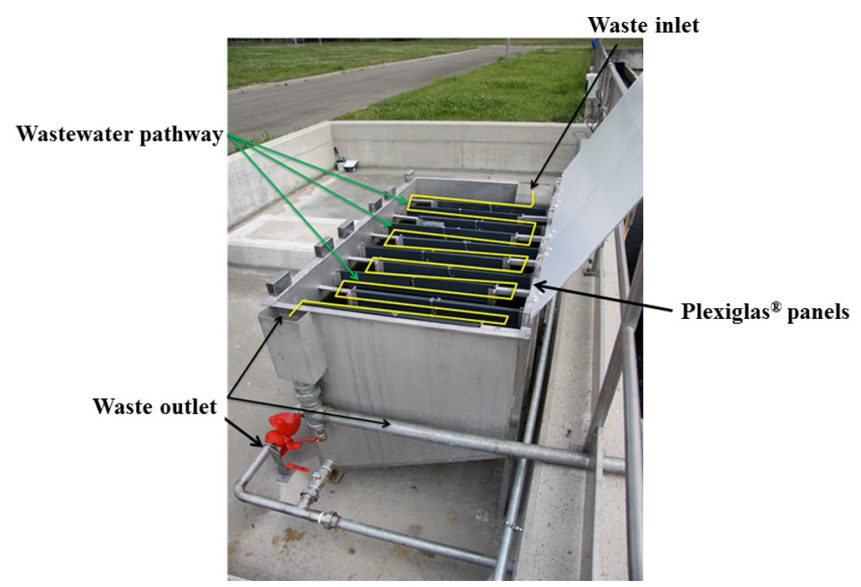

Fig. 2. Plexiglas ${ }^{\mathbb{R}}$ panels placed into the pilot-plant. The yellow line indicates the zig-zag flow pathway of wastewater within the pilot-plant.

environmental pollutants (pharmaceuticals and personal care products and illicit drugs).

\section{Experimental design and samples collection}

As previously described, an important point was the necessity to evaluate the removal efficiency of $D$. polymorpha independently from any other settling process, which would remove the metals adsorbed on suspended solids. The filtering action of $D$. polymorpha was first evaluated on the effluent outflowing secondary settling. However, since this effluent had a very low COD $(\approx 10 \mathrm{mg} / \mathrm{L})$ and, consequently, a low suspended solid concentration (on which a relevant amount of MEs is normally adsorbed) $[39,40]$, the following tests were performed with three other different wastewater mixtures, previously filtered through a $1 \mathrm{~mm}$ mesh bag filter to remove coarse matter. This allowed us to evaluate the filtration efficiency of $D$. polymorpha on wastewater with polluting load and different amounts of suspended particulate, also taking into account that this bivalve selects particles for food with a diameter ranging between 15 and $40 \mu \mathrm{m}$ [41]. The mixtures used in the tests, in addition to $100 \%$ outlet, are the following: $25 \%$ inlet/ $75 \%$ outlet, $50 \%$ inlet $50 \%$ outlet and $100 \%$ inlet (wastewater incoming at WWTP). The ME removal evidence from wastewater were carried out through the measurement of their concentrations in the water samples taken from the pilot-plant with bivalves inside; at the same time, control tests were conducted into the pilot-plant without adhering animals. All tests were performed in triplicate. The ME removal progress was monitored for $4 \mathrm{~h}$, by sampling the wastewaters every $30 \mathrm{~min}$, which enabled to obtain the removal slope for each ME. We chose to evaluate the ME removal within $4 \mathrm{~h}$, taking into account that the treated wastewaters remain in the Milano-Nosedo WWTP for about $24 \mathrm{~h}$; thus, the selected time seemed to be a fair compromise in view of integrating the conventional treatment with limited dimensional requirements. To check the practicability of such assumptions, we carried out further final tests in single for a period of $24 \mathrm{~h}$, taking only two samples, one at the beginning and one at the end of the tests. The tests were conducted with an initial flow rate corresponding to $3500 \mathrm{~L} / \mathrm{h}$, which would imply $18 \mathrm{~min}$ contact time, recirculating the effluent in the pilot-plant 84 times to obtain an overall $24 \mathrm{~h}$ contact time. After each test, the entire pilot-plant was washed with tap water, to avoid memory-effects related to the
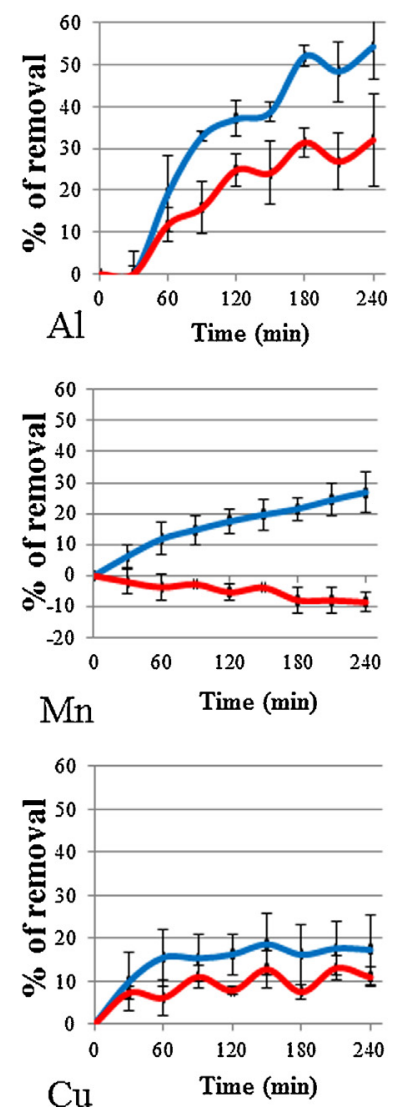

With $D$. polymorpha

Without $D$. polymorpha
$\mathbf{A}$

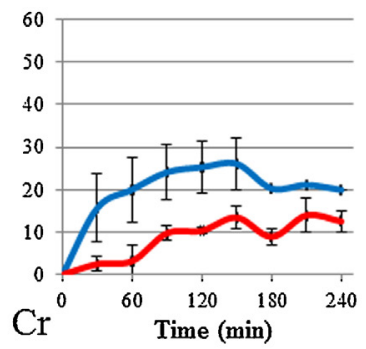

B

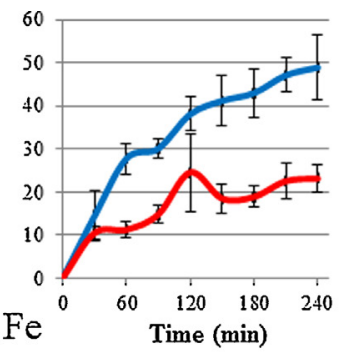

D

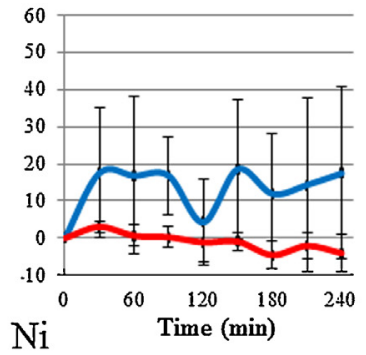

G

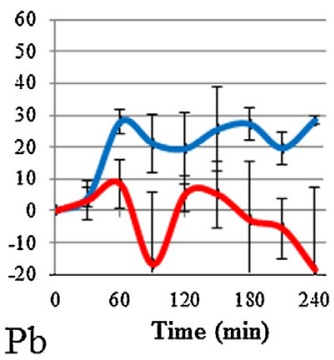

$\mathbf{E}$

C 
previous tests. For this reason, to minimize this problem, as well as to decrease the bivalve stress, the test schedule started with the most diluted waste (100\% outlet) and gradually increased its concentration until $100 \%$ inlet. We monitored the wastewater temperature both at the beginning and at the end of each test in order to take into account its possible interference with the filtration activity of zebra mussels. The wastewater temperature within the pilot-plant during the spring season ranged from 14 to $24^{\circ} \mathrm{C}$, comparable with the optimal values for D. polymorpha filtration activity $\left(10-20^{\circ} \mathrm{C}\right)$ [42]; we can thus exclude any negative interference of temperature on the filtration-removal process. Samples were taken from the pilot-plant at the selected times by the use of a $250 \mathrm{~mL}$ plastic bottles, acidified with $1 \%$ of $\mathrm{HNO}_{3}$ and stored at $4{ }^{\circ} \mathrm{C}$ at dark until analysis.

\section{Evaluation of ME abatement}

We evaluated the removal of some MEs relatively abundant in civil wastewaters: Aluminum $(\mathrm{Al})$, Chromium $(\mathrm{Cr})$, Copper $(\mathrm{Cu})$, Iron (Fe), Manganese (Mn), Nickel (Ni) and Lead (Pb). The samples, taken from the pilot-plant, were treated according to the CNR IRSA 3010 method. Briefly, an aliquot of each sample was transferred into a flask and heated up to $100^{\circ} \mathrm{C}$ to remove turbidity. After cooling, samples were brought back to the starting volume with distilled water. Samples were analyzed in a plasma optical emission spectrometer (ICP-OES; OPTIMA 2100 DV, PerkinElmer; detection limits for each ME: Al $0.5 \mu \mathrm{g} / \mathrm{L} ;$ Fe $0.2 \mu \mathrm{g} / \mathrm{L} ;$ Mn $0.1 \mu \mathrm{g} / \mathrm{L}$; Ni $0.5 \mu \mathrm{g} / \mathrm{L} ; \mathrm{Pb} 1.0 \mu \mathrm{g} / \mathrm{L} ; \mathrm{Cu} 0.5 \mu \mathrm{g} / \mathrm{L} ; \mathrm{Cr} 0.2 \mu \mathrm{g} / \mathrm{L}$ ) equipped with ultrasonic nebulizer (CETAC Ultrasonic Nebulizer, model U5000AT
$+)$. The ME concentrations were quantified by a calibration curve at two points, starting from appropriate dilutions of mixed certificate standard (AccuStandard MES 16-1).

\section{Statistical analyses}

Data normality and homoscedasticity were verified using the Shapiro-Wilk and Levene's tests, respectively. We performed a statistical comparison (SPSS 21 IBM software package) between tests carried out with and without mussels in the pilot-plant, where the dependent variable is the ME concentration in the wastewater and the fixed factors are the treatment and the exposure time. For all these cases, we conducted the comparison using the two-way analysis of variance (two-way ANOVA; $\left.{ }^{*} p<0.05 ;{ }^{* *} p<0.01\right)$.

\section{Results and discussion}

Evaluation of D. polymorpha filtering ability in the ME removal

The results obtained from the tests carried out with a $25 \%$ inlet/ $75 \%$ outlet mixture (Fig. 3A-G) showed a good removal performance by $D$. polymorpha due to the bio-filtration effect, probably because of the suitable concentration of the suspended matter. The removals obtained for each ME tested through the filtering activity of bivalves were always greater than those related to the natural sedimentation evaluated in controls. In fact, for the majority of the analyzed MEs, the contribution of the zebra mussel filtration was evident, since the differences between the removal percentage
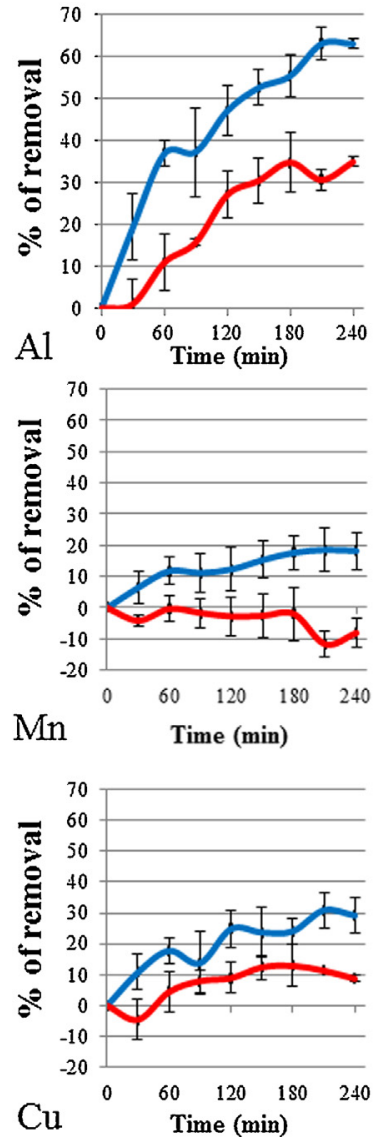

A

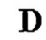

G
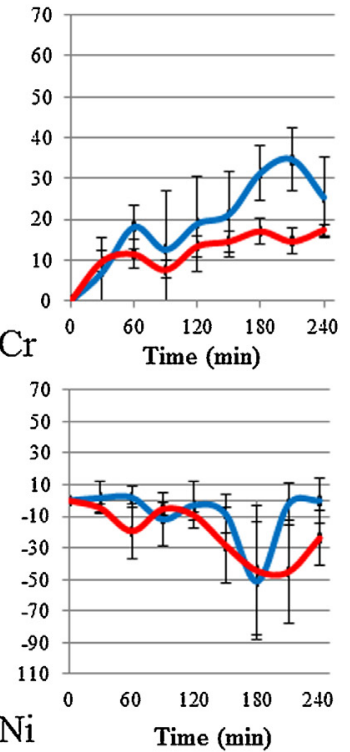

$\mathbf{E}$

B
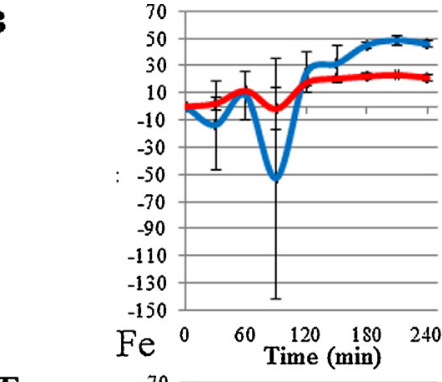

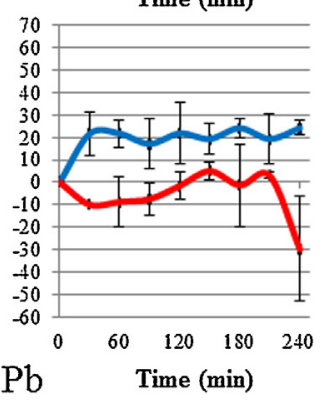

$\mathbf{F}$

C

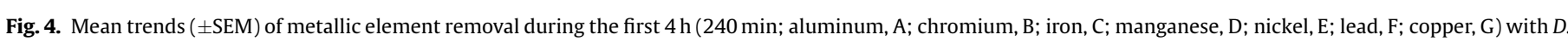

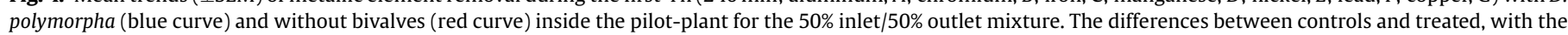
exception of nickel and iron, were statistically significant (two-way ANOVA). 
with and without bivalves in the pilot-plant were statistically significant: $\mathrm{Al}(F=36.809, p<0.01)$; $\mathrm{Fe}(F=62.686, p<0.01)$; $\mathrm{Mn}$ $(F=125.452, p<0.01)$; $\mathrm{Ni}(F=5.695, p<0.05) ; \mathrm{Pb} \quad(F=16.645$, $p<0.01)$; $\mathrm{Cu}(F=6.220, p<0.05)$. In detail, observing the trends reported in Fig. 3, it has to be highlighted that the differences between the removal percentages measured at the end of the tests reached the $30 \%$ for $\mathrm{Fe}$ and $\mathrm{Pb}$, while for $\mathrm{Al}, \mathrm{Ni}$ and $\mathrm{Mn}$ the removal was about $20-25 \%$ higher than controls. Thus, in only $4 \mathrm{~h}$, zebra mussels have been able to significantly decrease levels of most of the tested MEs, even if the removal of Cu was only $8 \%$ higher than natural sedimentation. On the other hand, the time selection to conduct the tests is crucial for the possible engineering of the process that cannot be longer than few hours, since the entire cycle of the wastewater treatment ends in about $24 \mathrm{~h}$. Tests carried out by adding $50 \%$ of inlet to the WWTP outlet (Fig. 4A-G) showed a lower difference compared to control than the previous tests, probably due to an excessive presence of suspended particulate matter that determined a stress condition to the animals, which may require a longer time than $4 \mathrm{~h}$ to acclimate and begin the filtering process. Moreover, we cannot exclude the possible presence of toxic compounds into the inlet of WWTP that could have led to a further decrease in the filtration activity. Despite these possible interfering processes, we found statistically significant difference between tests carried out with bivalves in the pilot-plant and their respective controls for $\mathrm{Al}(F=68.587$ $p<0.01)$, Mn $(F=38.710, p<0.01), \mathrm{Pb}(F=26.183, p<0.01), \mathrm{Cu}$ $(F=22.861, p<0.01)$ and $\mathrm{Cr}(F=4.729, p<0.01)$. In this regard, at the end of the test the removal was around $20-25 \%$, comparable to the results obtained for the mixture $25 \%$ inlet/75\% outlet for $\mathrm{Al}, \mathrm{Mn}$, $\mathrm{Pb}$ and $\mathrm{Cu}$, while for the other tested metals it decreased dramatically. The fluctuating values obtained for $\mathrm{Ni}$ could be due to the low concentration of this metal in the analyzed wastewater ( $<10 \mu \mathrm{g} / \mathrm{L}$ ), taking into account the huge variability of pollutant load in the inlet wastewaters. The role of the initial concentrations of metallic elements into the considered mixtures (Table 1), which depends on the WWTP inlet, must always be considered when drawing conclusions in terms of percent removal: if these are very low, small variations (which could also be partly due to analytical reasons) assume relevant percent weight. In both the considered tests (25\% inlet/75\% outlet and 50\% inlet/50\% outlet mixtures) negative values of sedimentation, comprised in a range of -5 and $-10 \%$, are observable; these values are likely to be related to the coefficient of variation of the method used to perform the wastewater ME quantification. These data do not appear to be random, because, except for the fluctuating values of $\mathrm{Ni}$ (Fig. $4 \mathrm{E}$ ), $\mathrm{Mn}$ and $\mathrm{Pb}$ showed null sedimentation values in both tests performed (Fig. 3D,F and Fig. 4D,F). This result can be reasonably related to the chemical speciation phenomenon because these metals can probably be dissolved in water and not bounded to the particulate. Therefore, the observed $\mathrm{Mn}$ and $\mathrm{Pb}$ removal process carried out by $D$. polymorpha could mainly be related to bioaccumulation. Further studies are needed in order to deepen the knowledge about some of the above-mentioned aspects, as also suggested by Camusso et al. [43]. In this regard, the wastewater $\mathrm{pH}$ value, which influences the metal speciation, is kept constant in WWTPs and, therefore, should not compromise the D. polymorpha purification activity. Finally, with regard to the test with $100 \%$ inlet, there has been a serious decline in the bivalves' performance related to a high mortality of the animals (data not shown). This result further confirms how an excessive suspended particulate matter amount and the possible presence of toxic substances into the WWTP can decrease the bivalves filtering capacity and even compromise their health status. However, this aspect does not limit the possible engineering of this method, since it would be sufficient to control the particulate matter of the wastewater, as suggested by Binelli et al. [21]. Moreover, despite the suspended matter concentration represents a limiting factor of $D$. polymorpha filtering capacity, it should be noted that the specimens used in this study are the same used in the pharmaceuticals and illicit drugs removal process, described by Binelli et al. [21]. Despite an exposure to multiple pollutants, the bivalves' purifying ability is stable during the whole experimental trial, representing a sure advantage in the use of this very resistant organism. Furthermore, the data shown refer to the ME removal within the first $4 \mathrm{~h}$ of wastewaters exposure to $D$. polymorpha, and that the bivalves' performance can be improved with increasing contact time between mollusks and wastewater, as described below.

\section{Time influence on the ME removal by D. polymorpha}

Data obtained by the above-mentioned tests suggested that the contact time between wastewater and the filter-feeding bivalves was probably one of the most crucial parameters, affecting the extent of ME removal from wastewater. As previously mentioned, although the increase of contact time could be almost impossible at full scale, we decided to carry out tests $24 \mathrm{~h}$ long. On the basis of the results obtained at $4 \mathrm{~h}$, the $24 \mathrm{~h}$ tests were performed only on $25 \%$ inlet $/ 75 \%$ outlet and $50 \%$ inlet $/ 50 \%$ outlet mixtures. For most of the MEs, the removal due to mussel filtration was about $70 \%$ with the $25 \%$ inlet/75\% outlet mixture (Fig. 5A). The natural sedimentation, at the same time, removed $50 \%$ of $\mathrm{Cr}$ and $\mathrm{Fe}$ and, surprisingly, only $10-25 \%$ of $\mathrm{Cu}, \mathrm{Mn}$ and $\mathrm{Pb}$ (Fig. 5A). Thus, zebra mussels' filtration is able to increase the removal of $\mathrm{Pb}$ and $\mathrm{Mn}$ by about $60 \%$ with respect to the settling effect in blanks. Notably, $\mathrm{Cr}$ removal appeared very interesting because of its high toxicity for aquatic organisms [44,45]; in fact, $D$. polymorpha completely removed it in $24 \mathrm{~h}$, while the blank removal was only $50 \%$. Therefore, contact time seems to affect significantly the extent of ME removal by the filter-feeding bivalves, considering that at the end of the first $4 \mathrm{~h}$ the mean removal was $20 \%$ higher with $D$. polymorpha than in the blank tests. This was also confirmed in the test performed with the $50 \%$ inlet $/ 50 \%$ outlet mixture (Fig. 5B), where the ME removal due to $D$. polymorpha was always over $70 \%$. In particular, for $\mathrm{Cu}, \mathrm{Mn}$ and $\mathrm{Pb}$ the net removal due to $D$. polymorpha (calculated as the difference from the blank removal) was $50 \%, 70 \%$ and $60 \%$,

Table 1

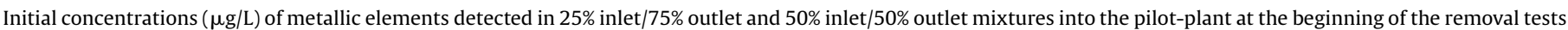

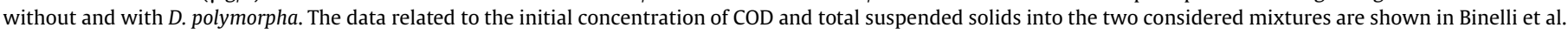
[21].

\begin{tabular}{|c|c|c|c|c|c|c|c|c|c|c|c|c|c|}
\hline \multicolumn{7}{|c|}{ Test without $D$. polymorpha } & \multicolumn{7}{|c|}{ Test with $D$. polymorpha } \\
\hline \multicolumn{14}{|c|}{$25 \%$ inlet $/ 75 \%$ outlet } \\
\hline $\mathrm{Al}$ & $\mathrm{Cr}$ & $\mathrm{Fe}$ & Mn & $\mathrm{Ni}$ & $\mathrm{Pb}$ & $\mathrm{Cu}$ & $\mathrm{Al}$ & $\mathrm{Cr}$ & $\mathrm{Fe}$ & Mn & $\mathrm{Ni}$ & $\mathrm{Pb}$ & $\mathrm{Cu}$ \\
\hline 56.6 & 2.5 & 802.4 & 41.9 & 5.2 & 2.7 & 11.7 & 67.5 & 1.5 & 249.2 & 15.1 & 3.3 & 3.0 & 11.7 \\
\hline \multicolumn{14}{|c|}{$50 \%$ inlet $/ 50 \%$ outlet } \\
\hline $\mathrm{Al}$ & $\mathrm{Cr}$ & $\mathrm{Fe}$ & Mn & $\mathrm{Ni}$ & $\mathrm{Pb}$ & $\mathrm{Cu}$ & $\mathrm{Al}$ & $\mathrm{Cr}$ & $\mathrm{Fe}$ & Mn & $\mathrm{Ni}$ & $\mathrm{Pb}$ & $\mathrm{Cu}$ \\
\hline 88.2 & 3.4 & 469.3 & 25.8 & 4.5 & 3.4 & 11.6 & 103.2 & 2.1 & 272.7 & 17.4 & 2.2 & 3.4 & 13.6 \\
\hline
\end{tabular}



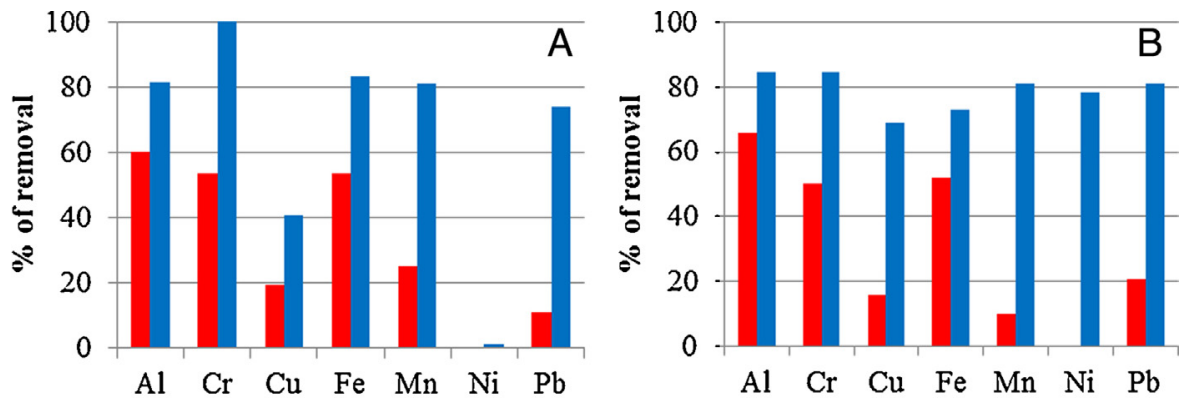

With D. polymorpha

Fig. 5. Removal percentage of metallic elements from wastewater after $24 \mathrm{~h}$ in the $25 \%$ inlet/75\% outlet (A) and $50 \%$ inlet/50\% outlet (B) mixtures.

respectively. At the same time, the high removal observed for $\mathrm{Ni}$ contradicts the results obtained in the experimental data set. The $24 \mathrm{~h}$ tests, although only performed in single and therefore needing further confirmation, provide first evidence that better ME removal performances may be obtained by increasing the contact time between the bivalves and the feed. Further, the obtained data may indicate that the bivalve could need a period of acclimation to the wastewater, especially if characterized by a considerable amount of suspended particulate material, before starting the filtration process.

\section{Future perspectives}

Due to the scarcity of scientific data regarding the use of $D$. polymorpha in the wastewater treatment context, we faced many technical and logistical problems during our research, not foreseeable during the experimental design drafting; in fact, the best performances of bio-filtration were obtained with prolonged exposure times $(24 \mathrm{~h})$ and with moderate amounts of particulates. Therefore, the ability of $D$. polymorpha to remove certain types of pollutants from pretreated wastewater could suggest, in a possible future research or in an engineered scenario, the placement of this filter-feeding bivalve as the last step of conventional WWTPs or to include it in other natural systems, such as constructed wetlands or lagooning, where the hydraulic retention time is of one or more days, and thus a longer contact time between wastewater and the bivalves is allowed. Furthermore, in future studies, it would be interesting to investigate the ME removal mechanisms and to monitorate the fate and presence of MEs in the bivalve soft tissues, shells, feces and pseudofaeces.

\section{Conclusions}

This work, according to our knowledge, represents one of the very few studies concerning the possibility to use bivalves in the wastewater treatment processes. The results appear to be very encouraging, considering that the use of non-native species, such as D. polymorpha, for anthropogenic purposes, could have interesting economic implications and represents an important starting point for the alien species exploitation. In this regard, the prevention strategies regarding the non-native and invasive species introduction determine complex social and ethical implications; furthermore, while the procedures on how to respond to invasions have been delineated, their application is still severely limited. Therefore, in the exclusive case of D. polymorpha, it may be advantageous to exploit the potential of this bivalve, now almost present in all the Europe inland waters. This will not certainly be an easy process; in fact, being D. polymorpha considered a serious threat for the aquatic environment and a dangerous fouling agent of many industrial structures [46,47], is poorly perceived by the scientific community as a valid filtering factor, despite the presence of encouraging results in the depuration context $[28,48,25,49,30,21]$. In this regard, the construction of appropriate facilities for bio-filtration, followed by further downstream treatment aimed to contain bivalves accidentally leaked from the plant (such as the peracetic acid treatment and sand filters) would avoid the problem related to fouling. The ideal condition would be to use native bivalves, such as unionids; however these mollusks, besides being affected by a serious population decline [50], have a parasite larval stage that would be disadvantageous for the engineering of the bio-filtration process. Once contaminated by the filtration process, the bivalves may then be dehydrated and stored in dedicated landfills or incinerated, as it is currently the case for sewage sludges.

\section{Acknowledgements}

We want to thank the Milano-Nosedo WWTP for the willingness in this study and for providing the facilities and areas, which have been essential to carry out the research. We also mean to mention the Aqualab Foundation for their support to this project and the Cariplo Foundation who co-funded this research.

\section{References}

[1] C.J. Williams, D. Aderhold, R.G.J. Edyvean, Comparison between biosorbents for the removal of metal ions from aqueous solutions, Water Res. 32 (1) (1998) 216-224, doi:http://dx.doi.org/10.1016/S0043-1354(97)00179-6.

[2] K. Kadirvelu, K. Thamaraiselvi, C. Namasivayam, Removal of heavy metals from industrial wastewaters by adsorption onto activated carbon prepared from an agricultural solid waste, Bioresour. Technol. 76 (1)(2001) 63-65, doi:http://dx doi.org/10.1016/S0960-8524(00)00072-9. 11315812.

[3] V.J. Inglezakis, M.D. Loizidou, H.P. Grigoropoulou, Ion exchange of $\mathrm{Pb} 2+$, $\mathrm{Cu} 2+$ $\mathrm{Fe} 3+$, and $\mathrm{Cr} 3+$ on natural clinoptilolite: selectivity determination and influence of acidity on metal uptake, J. Colloid Interface Sci. 261 (1) (2003) 4954, doi:http://dx.doi.org/10.1016/S0021-9797(02)00244-8.

[4] R. Mailler, J. Gasperi, V. Rocher, S. Gilbert-Pawlik, D. Geara-Matta, R. Moilleron, G. Chebbo, Biofiltration vs conventional activated sludge plants: what about priority and emerging pollutants removal? Environ. Sci. Pollut. Res. Int. 21 (8) (2014) 5379-5390, doi:http://dx.doi.org/10.1007/s11356-013-2388-0. 24366825.

[5] J.T. Matheickal, Q. Yu, J. Feltham, $\mathrm{Cu}^{(\mathrm{II})}$ binding by E. Radiata biomaterial, Environ. Technol. 18 (1) (1997) 25-34, doi:http://dx.doi.org/10.1080/ 09593331808616509.

[6] B.W. Atkinson, F. Bux, H.C. Kasan, Considerations for application of biosorption technology to remediate metal contaminated industrial effluents, Water S. A. 24 (2) (1998) 129-135.

[7] S.S. Ahluwalia, D. Goyal, Microbial and plant derived biomass for removal of heavy metals from wastewater, Bioresour. Technol. 98 (12) (2007) 2243-2257, doi:http://dx.doi.org/10.1016/j.biortech.2005.12.006. 16427277.

[8] E. Guibal, C. Roulph, P. Le Cloirec, Uranium biosorption by a filamentous fungus Mucor miehei pH effect on mechanisms and performances of uptake, Water Res. 26 (8) (1992) 1139-1145, doi:http://dx.doi.org/10.1016/0043-1354(92) 90151-S.

[9] T.C. Beveridge, R.J. Doyle, Metal Ions and Bacteria, Wiley Interscience, New York, 1989. 
[10] B. Volesky, Z.R. Holan, Biosorption of Heavy Metals, CRC Press, Boca Raton, 1990, doi:http://dx.doi.org/10.1021/bp00033a001.

[11] M. Galun, E. Galun, B.Z. Siegel, P. Keller, H. Lehr, S.M. Siegel, Removal of metal ions from aqueous solutions by Penicillium biomass: kinetic and uptake parameters, Water Air Soil Pollut. 33 (3-4) (1987) 359-371, doi:http://dx.doi. org/10.1007/BF00294204.

[12] G.M. Gadd, Microbial control of heavy metal pollution, in: J.C. Fry, G.M. Gadd, R A. Herbert, C.W. Jones, I.A. Watson-Craik (Eds.), Microbial Control of Pollution, Cambridge University Press, Cambridge, 1992.

[13] K.R. Reddy, D.L. Sutton, Waterhyacinths for water quality improvement and biomass production, J. Environ. Qual. 13 (1) (1984) 1-8, doi:http://dx.doi.org $10.2134 /$ jeq1984.00472425001300010001x.

[14] E. Pip, J. Stepaniuk, Cadmium, copper and lead in sediments and aquatic macrophytes in the lower Nelson river system, Manitoba, Canada, in: interspecific differences and macrophyte-sediment relations, Arch. Hydrobiol. 124 (1992) 337-355.

[15] G. Certini, R. Scalenghe, La depurazione delle acque reflue in sistemi seminaturali, Agribusiness Paesaggio Ambiente 3 (1999) 29-37.

[16] S. Dhote, S. Dixit, Water quality improvement through macrophytes-a review Environ. Monit. Assess. 152 (1-4) (2009) 149-153, doi:http://dx.doi.org/ 10.1007/s10661-008-0303-9. 18537050.

[17] F.D. Ledda, R. Pronzato, R. Manconi, Mariculture for bacterial and organic waste removal: a field study of sponge filtering activity in experimental farming, Aqua. Res. 45 (8) (2014) 1389-1401, doi:http://dx.doi.org/10.1111/are.12084.

[18] J.D. Ackerman, Effect of velocity on the filter feeding of dreissenid mussels (Dreissena polymorpha and Dreissena bugensis): implications for trophic dynamics, Can. J. Fish. Aquat. Sci. 56 (9) (1999) 1551-1561, doi:http://dx.doi.org/ 10.1139/f99-079.

[19] B.S. Baldwin, M.S. Mayer, J. Dayton, N. Pau, J. Mendilla, M. Sullivan, A. Moore, A. Ma, E.L. Mills, Comparative growth and feeding in zebra and quagga mussels (Dreissena polymorpha and Dreissena bugensis): implications for North American lakes, Can. J. Fish. Aquat. Sci. 59 (4) (2002) 680-684, doi:http://dx. doi.org/10.1139/f02-043.

[20] D.A. Pathy, The life history and demography of zebra mussel, Dreissena polymorpha, populations in Lake St. Clair, Lake Erie, and Lake Ontario, M. Sc. Thesis, vol. 33/02, University of Guelph, Guelph, Ontario, 1994.

[21] A. Binelli, S. Magni, C. Soave, F. Marazzi, E. Zuccato, S. Castiglioni, M. Parolini, V. Mezzanotte, The biofiltration process by the bivalve D. Polymorpha for the removal of some pharmaceuticals and drugs of abuse from civil wastewaters, Ecol. Eng. 71 (2014) 710-721, doi:http://dx.doi.org/10.1016/j.ecoleng.2014.08.004.

[22] T.J. Naimo, A review of the effects of heavy metals on freshwater mussels Ecotoxicology 4 (6) (1995) 341-362, doi:http://dx.doi.org/10.1007/ BF00118870. 24197828.

[23] H.H. Reeders, A. Bij de Vaate, Bioprocessing of polluted suspended matter from the water column by the zebra mussel (Dreissena polymorpha Pallas), Hydrobiologia 239 (1) (1992) 53-63, doi:http://dx.doi.org/10.1007/BF00027529.

[24] H. Silverman, J.W. Lynn, T.H. Dietz, Particle capture by the gills of Dreissena polymorpha: structure and function of latero-frontal cirri, Biol. Bull. 191 (1) (1996) 42-54, doi:http://dx.doi.org/10.2307/1543060.

[25] P. Elliott, D.C. Aldridge, G.D. Moggridge, Zebra mussel filtration and its potential uses in industrial water treatment, Water Res. 42 (2008) 1664-1674, doi:http://dx.doi.org/10.1016/j.watres.2007.10.020. 17996272.

[26] R. Sousa, J.L. Gutiérrez, D.C. Aldridge, Non-indigenous invasive bivalves as ecosystem engineers, Biol. Invasions 11 (10) (2009) 2367-2385, doi:http://dx. doi.org/10.1007/s10530-009-9422-7.

[27] Z. Piesik, Biology of Dreissena polymorpha (Pall.) settling on stylon nets and the role of this mollusc in eliminating the seston and the nutrients from the watercourse, Pol. Arch. Hydrobiol. 30 (1983) 353-361.

[28] A.F. Richter, Biomanipulation and its feasibility for water quality management in shallow eutrophic water bodies in the Netherlands, Hydrobiol. Bull. 20 (1-2) (1986) 165-172, doi:http://dx.doi.org/10.1007/BF02291160.

[29] N. Stybel, C. Fenske, G. Schernewski, Mussel cultivation to improve water quality in the Szczecin lagoon, J. Coast. Res. 56 (2009) 1459-1463.
[30] C. McLaughlan, D.C. Aldridge, Cultivation of zebra mussels (Dreissena polymorpha) within their invaded range to improve water quality in reservoirs, Water Res. 47 (13) (2013) 4357-4369, doi:http://dx.doi.org/10.1016/j. watres.2013.04.043. 23764587.

[31] R. Sousa, A. Novais, R. Costa, D.L. Strayer, Invasive bivalves in fresh waters: impacts from individuals to ecosystems and possible control strategies, Hydrobiologia 735 (1) (2014) 233-251, doi:http://dx.doi.org/10.1007/s10750012-1409-1.

[32] Ya.J. Starobogatov, S.I. Andreeva, Distribution and history, in: Ya.I. Starobogatov (Ed.), Frashwater Zebra Mussel Dreissena polymorpha (Pall.) (Bivalvia, Dreissenidae), Systematics, Ecology, Practical Meaning, Nauka Press, Moscow, Russia, 1994.

[33] S. Olenin, M. Orlova, D. Minchin, Dreissena polymorpha (Pallas, 1771), in: S. Gollasch, D. Minchin, H. Rosenthal, M. Voigt (Eds.), Case Histories on Introduced Species: Their General Biology, Distribution, Range Expansion and Impact, Logos-Verlag, Berlin, Germany, 1999.

[34] F. Giusti, E. Oppi, Dreissena polymorpha (Pallas) nuovamente in Italia. (Bivalvia, Dreissenidae), Mem. Mus. Civ. St. Nat. Verona 20 (1973) 45-49.

[35] C. Spilinga, U. Chiappafreddo, Q. Pirisinu, Dreissena polymorpha (Pallas) al lago Trasimeno, Riv. Idrobiol. 39 (2000) 145-152.

[36] M.Bodon, S.Cianfanelli, G. Manganelli, L.Castagnolo, E. Pezzoli, F. Giusti, Mollusca Bivalvia, in: S. Ruffo, F. Stoch eds, Checklist e distribuzione della fauna italiana, Mem. Mus.Civ. St. Nat. Verona 2. Serie, Sez. Scienze della Vita, (2005) 83-84.

[37] Cianfanelli, S., Lori, E., Bodon, M., Non-indigenous freshwater molluscs and their distribution in Italy in: Biological Invaders in Inland Waters: Profiles, Distribution, and Threats (2007). Springer, Netherlands

[38] A. Gantayet, L. Ohana, E.D. Sone, Byssal proteins of the freshwater zebra mussel, Dreissena polymorpha, Biofouling 29 (1) (2013) 77-85, doi:http://dx. doi.org/10.1080/08927014.2012.746672. 23211030.

[39] A. Tessier, P.G.C. Campbell, Partitioning of trace metals in sediments: relationships with bioavailability, Hydrobiologia 149 (1) (1987) 43-52, doi:http:// dx.doi.org/10.1007/BF00048645.

[40] W. Calmano, J. Hong, U. Förstner, Binding and mobilization of heavy metals in contaminated sediments affected by $\mathrm{pH}$ and redox potential, Water Sci. Technol. 28 (8-9) (1993) 223-235.

[41] E.H.T. Winkel, C. Davids, Food selection by Dreissena polymorpha Pallas (Mollusca: bivalvia), Freshwater Biol. 12 (6) (1982) 553-558, doi:http://dx.doi. org/10.1111/j.1365-2427.1982.tb00647.x.

[42] R.F. McMahon, The physiological ecology of the zebra mussel, Dreissena polymorpha, in North America and Europe, Integr. Comp. Biol. 36 (3) (1996) 339363, doi:http://dx.doi.org/10.1093/icb/36.3.339.

[43] M. Camusso, R. Balestrini, A. Binelli, Use of zebra mussel (Dreissena polymorpha) to assess trace metal contamination in the largest Italian subalpine lakes, Chemosphere 44 (2) (2001) 263-270, doi:http://dx.doi.org/10.1016/ S0045-6535(00)00169-7. 11444309.

[44] J.O. Nriagu, E. Nieboer, Chromium in the Natural and Human Environments, Wiley Interscience, New York, 1988.

[45] P. Chandra, K. Kulshreshtha, Chromium accumulation and toxicity in aquatic vascular plants, Bot. Rev. 70 (3) (2004) 313-327, doi:http://dx.doi.org/10.1663/ 0006-8101(2004)070[0313:CAATIA]2.0.CO;2.

[46] R. Claudi, G.L. Mackie, Practical Manual for Zebra Mussel Monitoring and Control, Lewis, Boca Raton, Florida, 1994.

[47] P. Elliott, D.C. Aldridge, G.D. Moggridge, M. Chipps, The increasing effects of zebra mussels on water installations in England, Water Environ. J. 19 (4) (2005) 367-375, doi:http://dx.doi.org/10.1111/j.1747-6593.2005.tb00575.x.

[48] A.E. Antsulevich, Artificial reefs project for improvement of water quality and environmental enhancement of Neva Bay (St. Petersburg County region), Bull. Mar. Sci. 55 (2?3) (1994) 1189-1202.

[49] G. Schernewski, N. Stybel, T. Neumann, Zebra mussel farming in the Szczecin (Oder) lagoon: water-quality objectives and cost-effectiveness, Ecol. Soc. 17 (2) (2012) 4, doi:http://dx.doi.org/10.5751/ES-04644-170204.

[50] A.E. Bogan, Freshwater bivalve extinctions (Mollusca: Unionoida): a search for causes, Integr. Comp. Biol. 33 (6) (1993) 599-609, doi:http://dx.doi.org/ 10.1093/icb/33.6.599. 